\title{
PERBEDAAN KINERJA KONSELOR BERSERTIFIKAT PENDIDIK DENGAN YANG BELUM BERSERTIFIKAT PENDIDIK DALAM LAYANAN BIMBINGAN DAN KONSELING
}

\author{
Eli Trisnowati \\ Program Studi Bimbingan dan Konseling \\ Fakultas Ilmu Pendidikan dan Pengetahuan Sosial IKIP PGRI Pontianak \\ Jalan Ampera Nomor 88 Pontianak - 78116, Telepon (0561) 748219 Fax. (0561) 589855 \\ Alamat e-mail: elisurawadi@gmail.com
}

\begin{abstract}
Abstrak
Tujuan penelitian ini adalah mengetahui secara empiris perbedaan kinerja konselor yang telah bersertifikat pendidik dengan yang belum bersertifikat pendidik. Metode penelitian adalah metode komparasi. Hasil penelitian konselor bersertifikat pendidik menunjukkan bahwa pada layanan orientasi memperoleh nilai rata - rata $95,91 \%$, informasi $93,51 \%$, penempatan dan penyaluran $91,35 \%$, penguasaan konten $92,95 \%$, konseling perorangan $87,82 \%$, bimbingan kelompok $91,21 \%$, konseling kelompok $92,58 \%$, konsultasi $91,67 \%$, dan mediasi $91,67 \%$ semua dengan presentase sangat baik. Sedangkan konselor yang belum bersertifikat pendidik menunjukkan bahwa pada layanan orientasi memperoleh nilai rata - rata 70,77\%, informasi $70,96 \%$, penempatan dan penyaluran $69,36 \%$, penguasaan konten $68,14 \%$, konseling perorangan $68,14 \%$, bimbingan kelompok $66,81 \%$, konseling kelompok $65,76 \%$, konsultasi $67,16 \%$, dan mediasi $67,89 \%$ semua berdominan dengan presentase cukup baik. Hasil uji $t$-tes menunjukkan bahwa nilai t hitung 40.139 dan t tabel dengan 5\% adalah 2,042, jadi $\mathrm{t}$ hitung $>\mathrm{t}$ tabel maka hasilnya yaitu terdapat perbedaan yang signifikan. Simpulan dari penelitian ini adalah terdapat perbedaan.
\end{abstract}

Kata kunci : Kinerja Konselor, Layanan BK, Sertifikat Pendidik

\begin{abstract}
The purpose of this study is to know empirically the difference in the performance of counselors who have been certified educators with uncertified educators. The method of research is comparative method. The result of research by certified educator counselor shows that in orientation service get average value $95,91 \%$, information $93,51 \%$, placement and distribution $91,35 \%$, content content $92,95 \%$, individual counseling $87,82 \%$, group guidance $91.21 \%$, counseling group $92.58 \%, 91.67 \%$ consultation, and mediation $91.67 \%$ all with excellent percentage. While the counselor who has not certified educators shows that the orientation service obtained an average score of $70.77 \%$, information $70.96 \%$, placement and distribution $69.36 \%$, content content $68.14 \%$, individual counseling $68.14 \%$, guidance group 66,81\%, counseling group 65,76\%, consultation 67,16\%, and mediation $67,89 \%$ all dominate with good enough percentage. The results of t-test shows that the value of $t$ arithmetic 40.139 and $t$ table with 5\% is 2.042, so $t$ arithmetic $>t$ table then the result is there is a significant difference. The conclusion of this research is that there are differences.
\end{abstract}

Keywords: Counselor Performance, Guidance and counseling Service, Educator Certificate

\section{PENDAHULUAN}


Keberadaan Bimbingan dan Konseling dalam kerangka pendidikan merupakan salah satu bidang dalam proses pendidikan disamping bidang kurikulum dan pengajaran serta bidang administrasi dan supervisi. Sebagai salah satu bidang dalam pelaksanaan proses pendidikan di sekolah, Bimbingan dan Konseling merupakan wujud sadar dari pemerintah untuk membantu mencapai tujuan dari pendidikan yaitu perkembangan kepribadian yang optimal dari setiap peserta didik. Bimbingan dan Konseling bukanlah kegiatan pembelajaran dalam konteks adegan mengajar yang layaknya dilakukan guru sebagai pembelajaran bidang studi, melainkan layanan ahli dalam konteks memandirikan peserta didik. (Naskah Akademik ABKIN, Penataan Pendidikan Profesional Konselor dan Pelaksanaan Bimbingan dan Konseling dalam Jalur Pendidikan Formal, 2007).

Salah satu pengaruh kesuksesan dalam perkembangan kepribadian yang optimal dari setiap peserta didik yaitu adanya ketercapaian kinerja Konselor yang baik dan memenuhi profesionalitas guru. Untuk dapat mencapai kinerja Konselor yang baik, Konselor harus melaksanakan tugasnya dengan baik pula. Tugas Konselor adalah membantu siswa agar lebih optimal dalam segala bidang. Kinerja Konselor merupakan proses perilaku kerja Konselor sehingga menghasilkan sesuatu yang menjadi tujuan pekerjaan profesinya. Tugas Konselor adalah mengenal siswa dengan berbagai karakteristiknya dan pengembangan diri peserta didik yang sesuai dengan kebutuhan, potensi, bakat, minat, dan kepribadian peserta didik di sekolah. Hal tersebut dapat dilakukan melalui layanan Bimbingan dan Konseling dengan format perorangan, kelompok, maupun klasikal.

Kinerja Konselor dalam memberikan layanan Bimbingan dan Konseling yaitu proses perilaku kerja Konselor dalam memberikan layanan Bimbingan dan Konseling yang meliputi misalnya layanan informasi, layanan orientasi, layanan penguasaan konten, dan juga layanan penempatan dan penyaluran, layanan konseling perorangan, layanan bimbingan kelompok, layanan konseling kelompok, layanan konsultasi, dan layanan mediasi. Kinerja konselor dalam memberikan layanan Bimbingan dan Konseling sangat berpengaruh untuk pembentukan kepribadian peserta didik dan membantu memenuhi kebutuhan peserta didik dalam perkembangan dirinya untuk mencapai optimal. Apabila 
kinerja Konselor baik dan sesuai dalam memberikan layanan Bimbingan dan Konseling maka akan baik pula peserta didik dalam memahami layanan Bimbingan dan Konseling dan menempatkan layanan Bimbingan dan Konseling sesuai dengan kebutuhan peserta didik masing-masing. Sedangkan apabila Konselor dalam kinerjanya memberikan layanan Bimbingan dan Konseling tidak sesuai dengan prosedur layanan Bimbingan dan Konseling yang telah ditetapkan pendidikan Bimbingan dan Konseling maka akan terjadi ketidak sesuaian fungsi dari layanan tersebut.

Idealnya Konselor sekolah juga memperhatikan kinerja Konselor yang baik. Kinerja Konselor mencakup empat komponen. Pertama Konselor harus membuat perencanaan kegiatan yang berupa program bimbingan mulai dari program tahunan, semesteran, bulanan, mingguan, dan harian. Kedua, Konselor mengorganisasikan berbagai unsur dan sarana yang akan dilibatkan dalam kegiatan layanan yang telah direncanakan dalam program sebelumnya. Ketiga, Konselor melaksanakan konseling dengan berbagai jenis layanan dan kegiatan pendukung sesuai dengan masing-masing kegiatan yang telah direncanakan dan diorganisasikan. Ketiga, Konselor melaksanakan konseling dengan berbagai jenis layanan dan kegiatan pendukung sesuai dengan masing-masing kegiatan yang telah direncanakan dan diorganisasikan. Kinerja Konselor dalam pelaksanaan layanan Bimbingan dan Konseling yang dimaksud yaitu kesesuian pelaksanan layanan bimbingan dan konseling yang terdiri dari layanan orientasi, layanan informasi, layanan penempatan penyaluran, layanan penguasaan konten, layanan konseling perorangan, layanan bimbingan kelompok, layanan konseling kelompok, layanan konsultasi, dan layanan mediasi sesuai dengan prosedur pelaksanaannya di sekolah.

Layanan Bimbingan dan Konseling diharapkan membantu peserta didik dalam pengenalan diri, pengenalan lingkungan dan pengambilan keputusan, serta memberikan arahan terhadap perkembangan peserta didik; tidak hanya untuk peserta didik yang bermasalah tetapi untuk seluruh peserta didik. Layanan Bimbingan dan Konseling tidak terbatas pada peserta didik tertentu atau yang perlu "dipanggile saja, melainkan untuk seluruh peserta didik. Kegiatan 
bimbingan dan konseling disekolah tidak terlepas dari layanan-layanan yang ada, layanan tersebut meliputi layanan orientasi, layanan informasi, layanan penempatan penyaluran, layanan penguasaan konten, layanan konseling individu, layanan bimbingan kelompok, layanan konseling kelompok, layanan konsultasi, layanan mediasi. Maka terselenggaranya kinerja konselor yang baik dalam memberikan layanan bimbingan dan konseling disekolah akan sangat membantu siswa untuk potensi-potensi yang ada pada diri masing-masing siswa, sehingga individu dapat mengetahui apa-apa yang menjadi potensi didalam dirinya baik dari sisi akademis maupun dari sisi non akademis. Untuk menciptakan kualitas pendidikan yang seperti dijelaskan uraian di atas maka pemerintah merujuk pada ketentuan Pasal 42 ayat [1] UU Sisdiknas, menuntut bahwa guru dan dosen wajib memiliki sertifikasi sesuai dengan jenjang kewenangan mengajar, sehat jasmani dan rohani, serta memiliki kemampuan untuk mewujudkan tujuan pendidikan nasional.

Pengertian sertifikasi adalah proses pemberian sertifikat pendidik kepada guru. Sertifikat pendidik diberikan kepada guru yang telah memenuhi standar profesional guru. Guru profesional merupakan syarat mutlak untuk menciptakan sistem dan praktik pendidikan yang berkualitas. Tujuan sertifikasi guru secara umum yaitu menentukan kelayakan guru dalam melaksanakan tugas sebagai agen pembelajaran dan mewujudkan tujuan pendidikan nasional. Selain itu tujuan yang utama untuk dapat menunjukan bahwa yang bersangkutan telah memiliki kompetensi sebagaimana disyaratkan dalam standar kompetensi guru. Tunjangan profesi adalah konsekuensi logis yang menyertai adanya kemampuan yang dimaksud. Dengan menyadari hal ini maka guru tidak akan mencari jalan lain guna memperoleh sertifikat profesi kecuali mempersiapkan diri dengan belajar yang benar untuk menghadapi sertifikasi.

Berdasarkan pengamatan di lapangan secara umum yang terjadi di beberapa sekolah di Kota Pontianak, melalui wawancara dengan konselor, kepala sekolah dan guru di beberapa sekolah adanya pandangan dan persepsi oleh kepala sekolah dan guru bahwa kinerja antara konselor yang telah memperoleh sertifikat pendidik secara teori itu lebih baik dari konselor yang belum memperoleh 
sertifikat pendidik. Karena memperoleh sertifikasi itu tidak mudah, harus melalui tes maupun PLPG. Tetapi ada juga kepala sekolah dan guru yang memandang bahwa konselor yang belum memporoleh sertifikat pendidik itu lebih baik kinerjanya, dan memandang konselor yang telah mendapatkan sertifikat pendidik malah jauh kurang baik kinerjanya karena merasa kelayakan hidupnya sebagai seorang guru telah dipenuhi.

Fenomena lain yang terjadi dalam pelaksanaan berbagai layanan bimbingan dan konseling salah satunya dalam pelaksanaan konseling individu ternyata masih terkesan belum sesuai dan terlampaui jauh dengan pemahaman teori yang di dapatkan konselor dalam pendidikan. Seorang konselor bersertifikat pendidik memanggil siswanya untuk diberikan layanan konseling individu namun ternyata bukan untuk diberi layanan konseling individu melainkan diinterogasi dan dinasehati mengenai perlakuan siswa yang dilakukan. Adalagi konselor bersertifikat pendidik selalu mengurusi dengan siswa yang sering terlambat, membolos, berkelahi, bahkan kadang sampai menghukumnya.

Berbeda dengan konselor yang telah bersertifikat pendidik, hal yang terjadi di sekolah A terdapat konselor yang belum bersertifikat pendidik lebih baik dari konselor yang telah bersertifikat pendidik dalam pelaksanaan layanan bimbingan dan konseling. Konselor yang belum tersertifikasi/ bersertifikat pendidik lebih memahami pelaksanaan konseling individu dan mengerti mengenai azas kerahasiaan konseli/ peserta didik. Berbeda dengan konselor yang telah tersertifikasi, bukanya menjaga masalah konseling dalam pelaksanaan konseling individu malah menceritakan dengan guru lain.

Dari uraian tersebut mengenai perbedaan kinerja konselor yang telah bersertifikat pendidik dengan konselor yang belum bersertifikat pendidik dalam pelaksanaan pelayanan bimbingan dan konseling, maka peneliti ingin mengetahui "apakah ada perbedaan kinerja konselor bersertifikat pendidik dengan konselor yang belum bersertifikat pendidik dalam pelaksanaan layanan BK?”.

Tujuan dari penelitian ini adalah untuk memperoleh data empiris mengenai perbedaan kinerja konselor yang bersertifikat pendidik dan yang belum bersertifikat pendidik dalam pelaksanaan layanan bimbingan dan konseling. 
Hipotesis penelitian yang diajukan dalam penelitian ini adalah "terdapat perbedaan kinerja konselor yang telah bersertifikat pendidik dengan konselor yang belum bersertifikat pendidik dalam pelaksanaan layanan Bimbingan dan Konseling."

\section{METODE}

Pendekatan yang digunakan dalam penelitian ini adalah metode kuantitatif yang oleh Azwar (2003:5) dijelaskan sebagai "suatu prosedur penelitian yang menekan pada data-data numerikal atau angka yang diolah dengan metode statistika”. Jenis penelitian ini adalah penelitian komparasi. Penelitian komparasi oleh Azwarni (dalam Arikunto, 2002:236) digunakan untuk menemukan persamaan-persamaan dan perbedaan tentang tanda-tanda, tentang orang, tentang prosedur kerja. Penelitian ini menggunakan dua variabel yaitu satu variabel bebas dan satu variabel terikat.Variabel bebas dalam penelitian ini adalah sertifikasi guru BK yang terdiri dari konselor bersertifikat pendidik dan konselor yang belum bersertifikat pendidik.Variabel terikat dalam penelitian ini adalah kinerja konselor dalam pelaksanaan layanan bimbingan dan konseling.

Adapun keterkaitan antara kedua variabel penelitian dapat dilihat pada gambar dibawah ini:

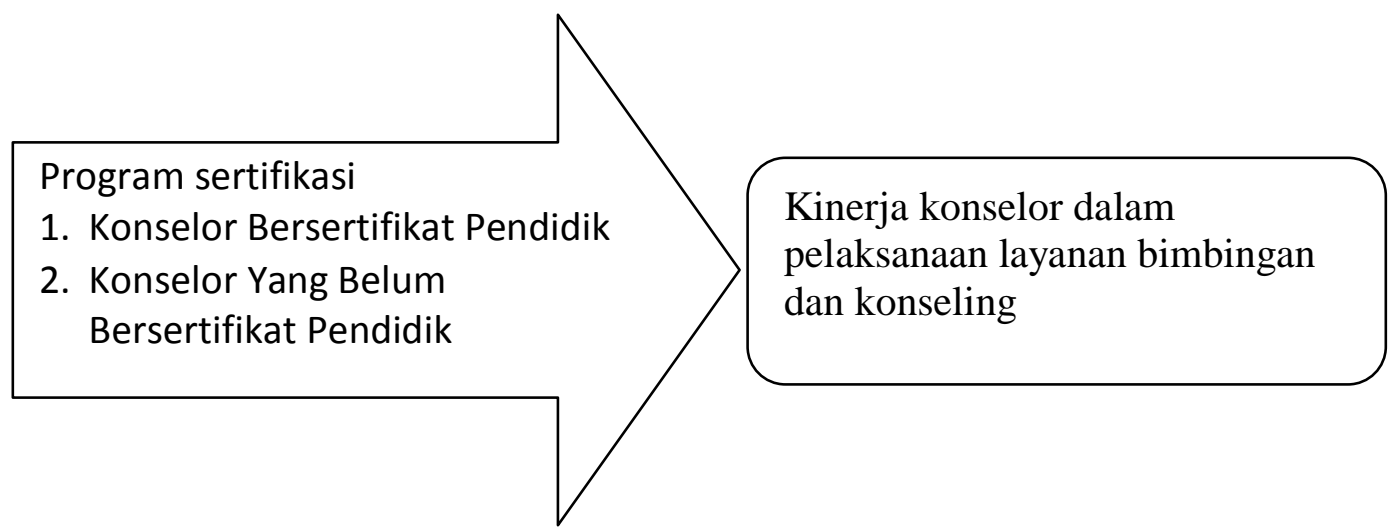

Populasi dalam penelitian ini adalah seluruh subyek dalam suatu penelitian atau individu yang akan diteliti. Populasi dan sampel dalam penelitian ini adalah seluruh konselor di SMA Negeri se-kota Pontianak yang berjumlah 9 sekolah 
dengan jumlah konselor 30 orang, 13 konselor bersertifikat pendidik dan 17 konselor yang belum bersertifikat pendidik.

Metode pengumpulan data menggunakan angket atau kuesioner. Metode angket digunakan karena penelitian ini bertujuan untuk mengetahui perbedaan kinerja konselor bersertifikat pendidik maupun konselor yang belum bersertifikat pendidik dalam pelaksanaan layanan bimbingan dan konseling.

\section{HASIL DAN PEMBAHASAN}

Berdasarkan hasil penelitian, didapatkan nilai rata-rata keseluruhan bahwa kinerja konselor bersertifikat pendidik dan konselor yang belum bersertifikat pendidik dalam pelaksanaan layanan BK berbeda. Hal ini dapat dilihat dalam bagan sebagai berikut:

\section{Gambar 1. Perbedaan Pelaksanaan Layanan Orientasi}

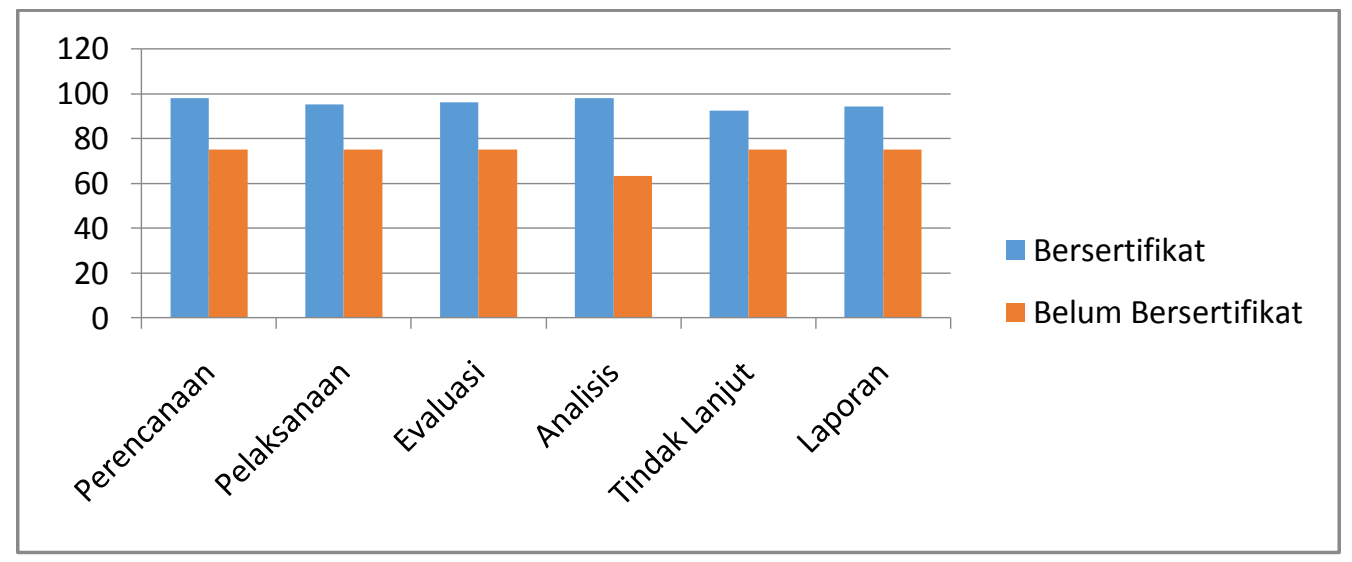

Gambar 2. Perbedaan Pelaksanaan Layanan Informasi

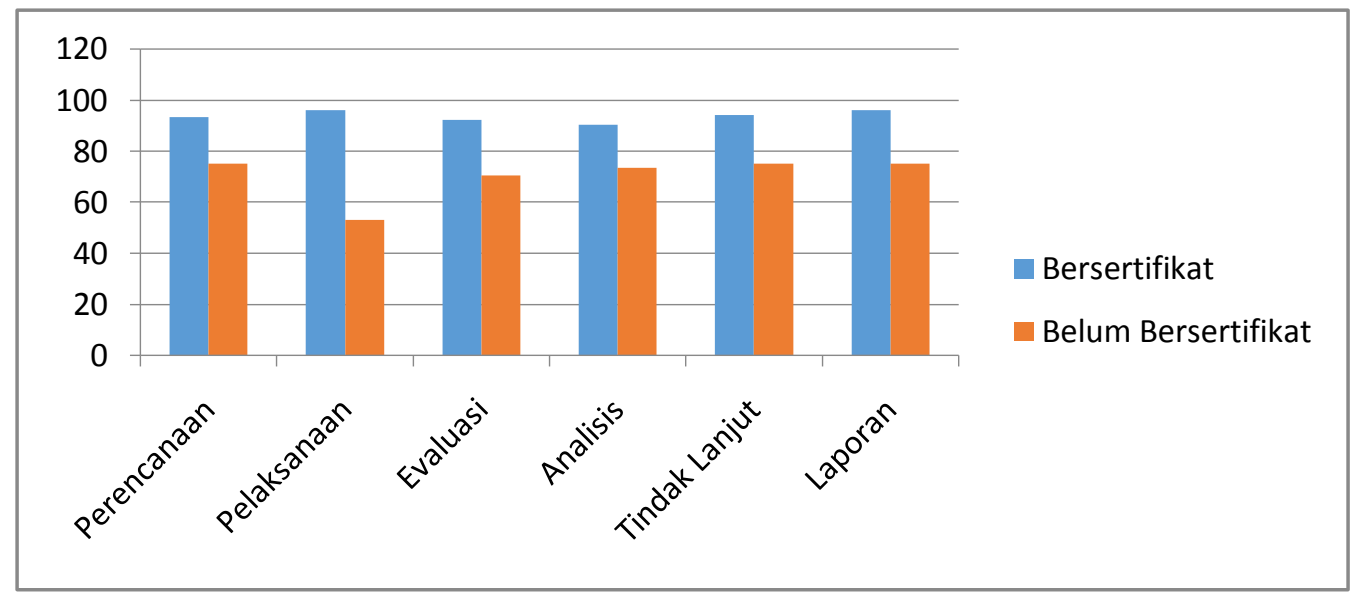


Gambar 3. Perbedaan Pelaksanaan Layanan Penyaluran dan Penempatan

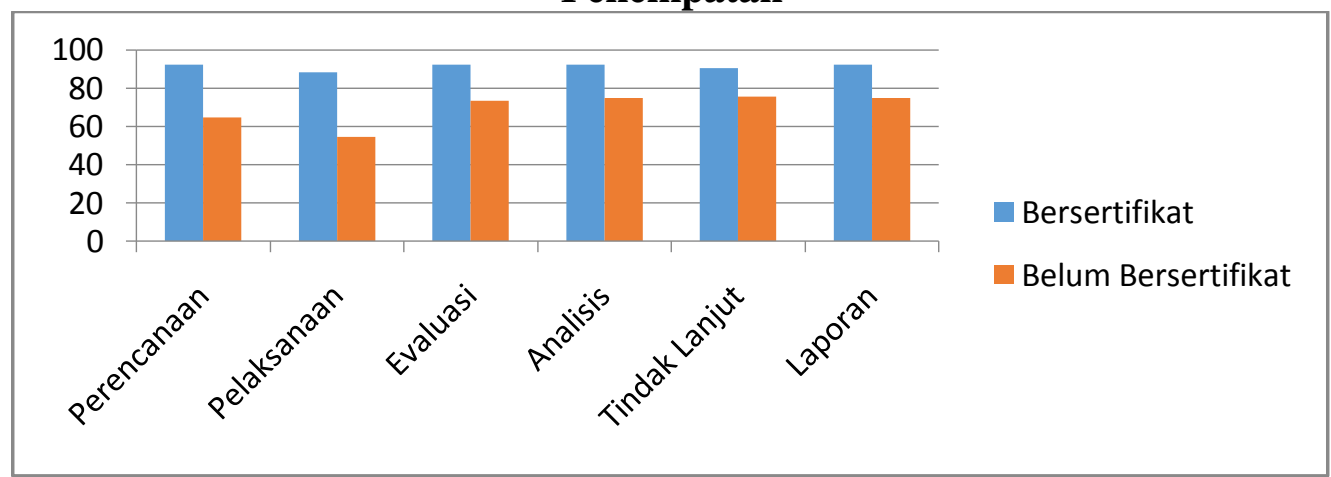

Gambar 4. Perbedaan Pelaksanaan Layanan Penguasaan Konten

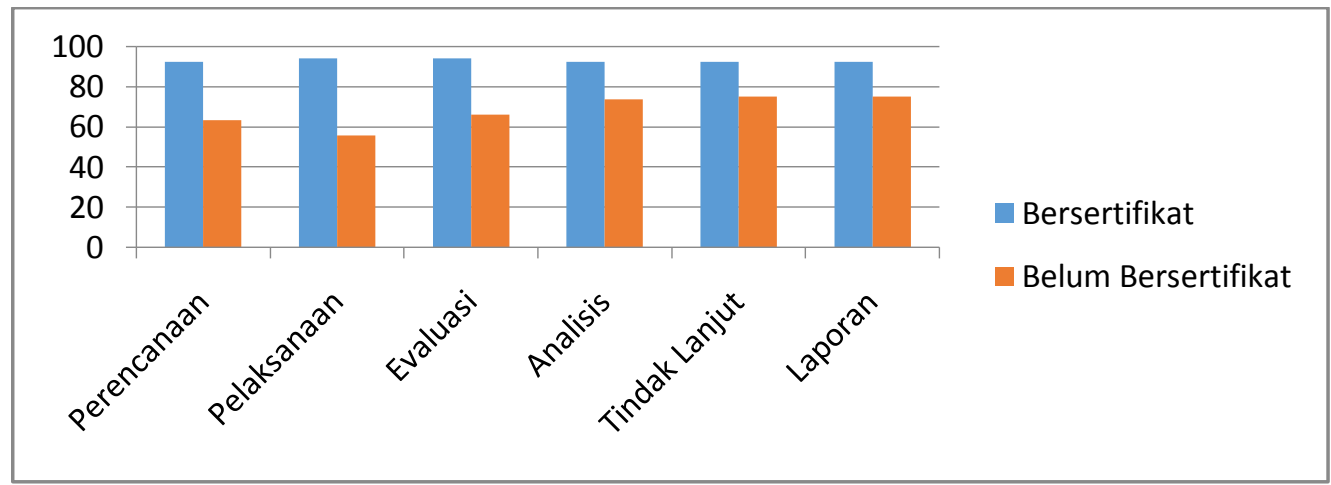

Gambar 5. Perbedaan Pelaksanaan Layanan Konseling Perorangan

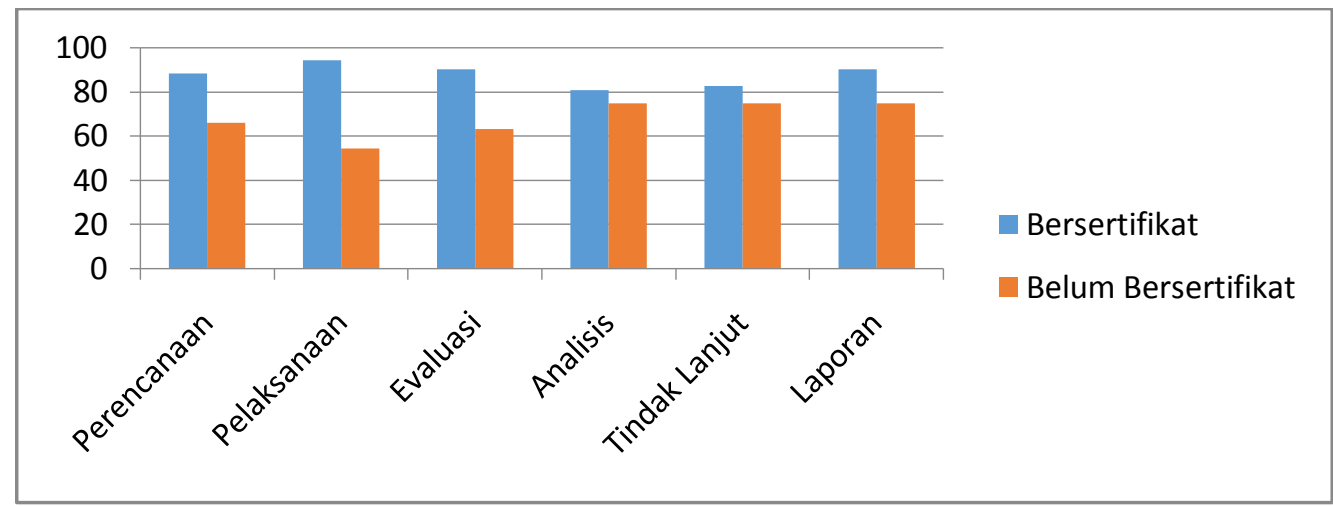


Gambar 6. Perbedaan Pelaksanaan Layanan Bimbingan Kelompok

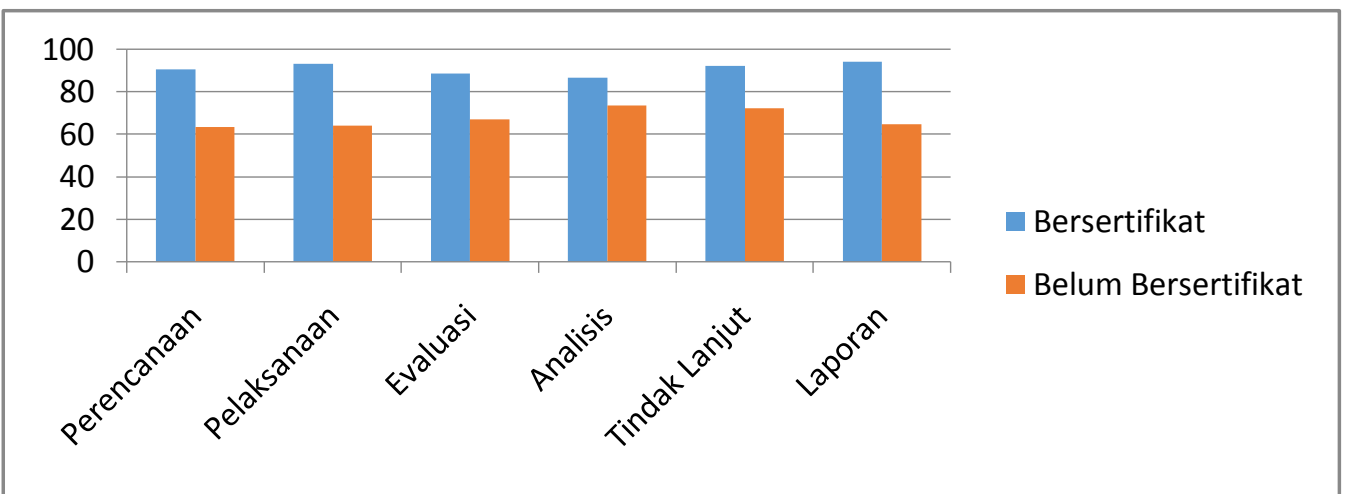

Gambar 7. Perbedaan Pelaksanaan Layanan Konseling Kelompok

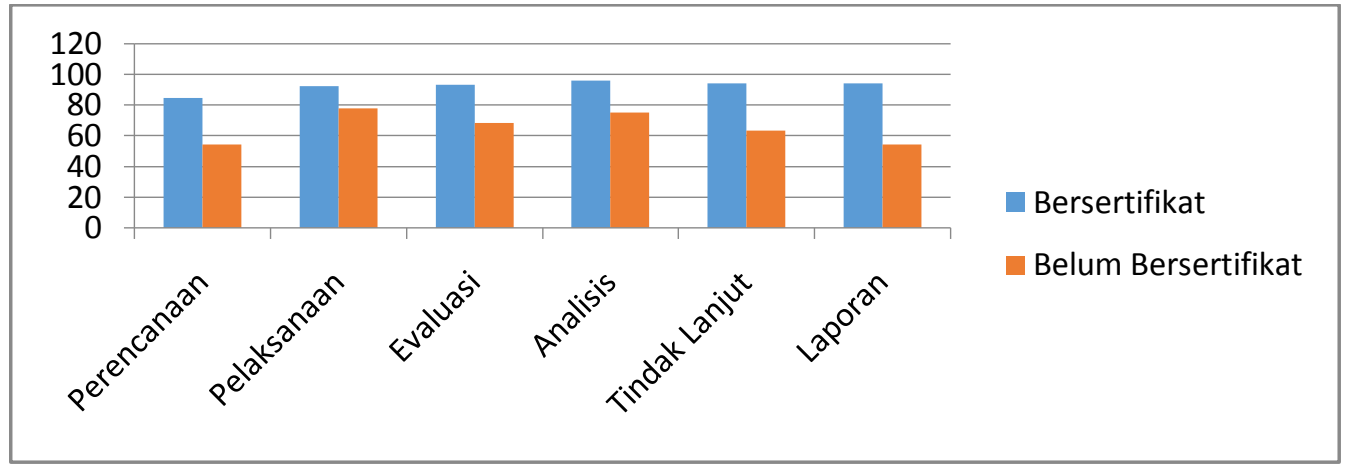

Gambar 8. Perbedaan Pelaksanaan Layanan Konsultasi

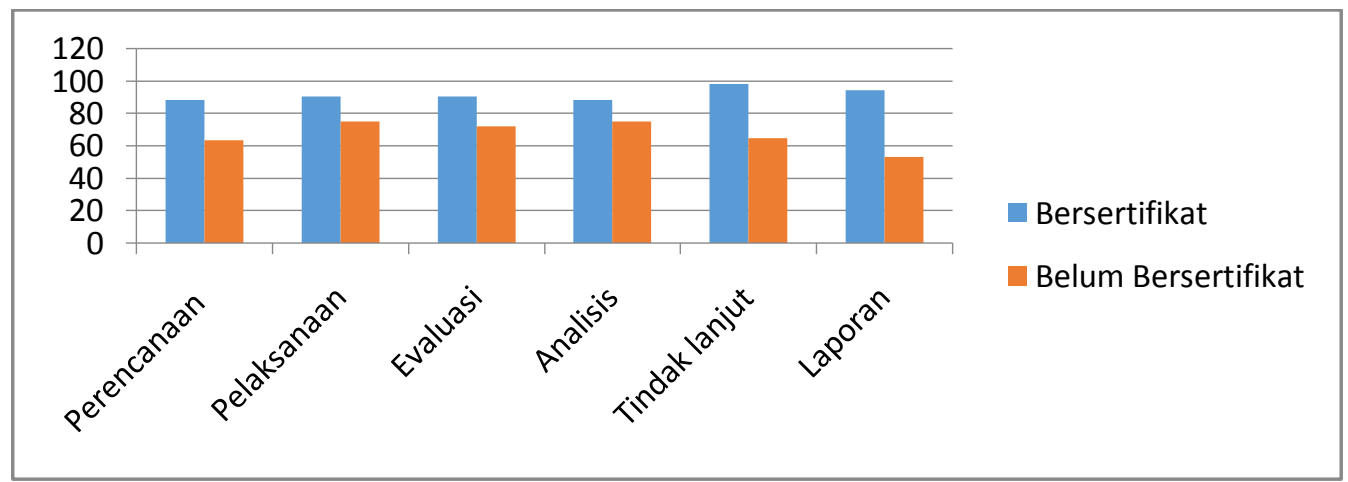




\section{Gambar 9. Perbedaan Pelaksanaan Layanan Mediasi}

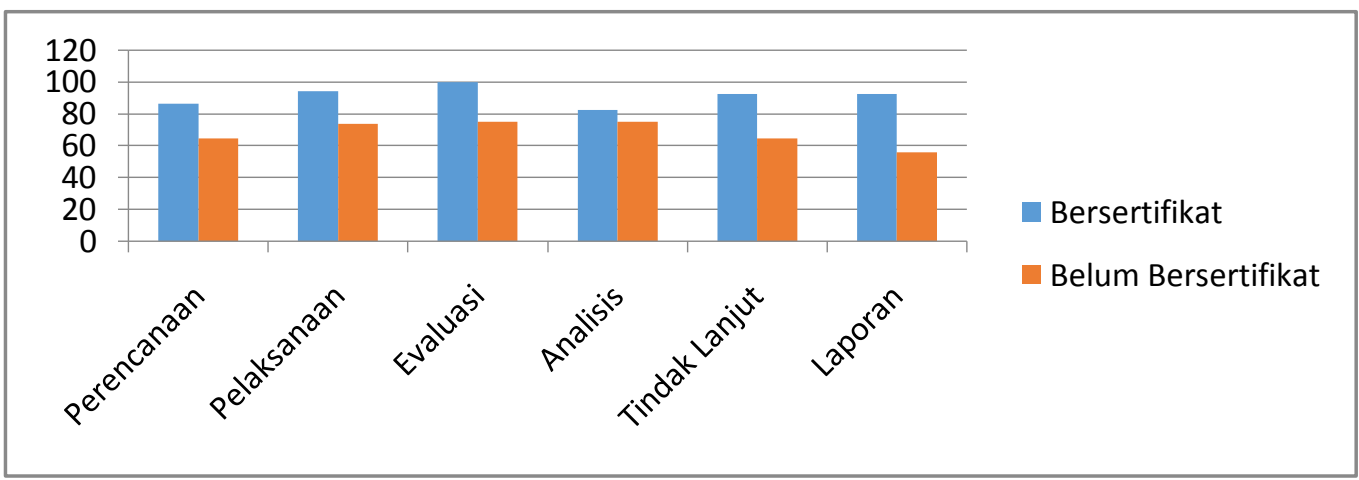

Pada konselor yang telah bersertifikat pendidik memiliki kinerja pada layanan orientasi memperoleh hasil rata-rata 95,91\% yang termasuk dalam kriteria sangat baik. Artinya konselor yang telah bersertifikat pendidik sudah sangat baik dalam pelaksanaan layananorientasi. Sedangkan pada konselor yang belum bersertifikat pendidik memperoleh hasil $70,77 \%$ yang termasuk dalam kriteria baik.

Kinerja konselor pada pelaksanaan layanan informasi diketahui bahwa konselor yang telah bersertifikat pendidik memperoleh hasil $93,51 \%$ dengan kriteria sangat baik. Artinya konselor yang telah bersertifikat pendidik sudah sangat baik dalam pelaksanaan layanan informasi. Sedangkan pada konselor yang belum bersertifikat pendidik memperoleh hasil 70,96\% dalam kriteria baik.

Kinerja konselor pada pelaksanaan layanan penempatan penyaluran pada konselor yang telah bersertifikat pendidik memperoleh hasil 91,35\% yang termasuk dalam kriteria sangat baik. Sedangkan pada konselor yang belum bersertifikat pendidik memperoleh $69,36 \%$ yang termasuk dalam cukup baik. Hal ini dapat disimpulkan bahwa konselor yang telah bersertifikat pendidik lebih baik dari pada konselor yang belum bersertifikat pendidik dalam pelaksanaan layanan penempatan penyaluran.

Kinerja konselor pada pelaksanaan layanan penguasaan konten pada konselor yang telah bersertifikat pendidik memperoleh hasil rata-rata 92,95\% yang termasuk dalam kriteria sangat baik. Artinya konselor yang telah bersertifikat pendidik sudah sangat baik dalam pelaksanaan layanan penguasaan 
konten. Sedangkan konselor yang belum bersertifikat pendidik memperoleh nilai $68,14 \%$ yang masuk dalam kriteria cukup baik. Hal ini dapat dilihat bahwa konselor yang telah bersertifikat pendidik lebih baik dari konselor yang belum bersertifikat pendidik.

Pada pelaksanaan layanan konseling perorangan konselor yang telah bersertifikat pendidik memiliki nilai rata-rata $87,82 \%$ yang termasuk dalam kriteria sangat baik. Artinya konselor yang telah bersertifikat pemdidik sudah sangat baik dalam pelaksanaan layanan konseling perorangan. Sedangkan konselor yang belum bersertifikat pendidik memperoleh nilai 68,14\% yang termasuk dalam kriteria cukup baik. Hal ini dapat dilihat bahwa konselor yang telah bersertifikat pendidik lebih baik dari konselor yang belum bersertifikat pendidik dalam pelaksanaan layanan konseling perorangan.

Pada pelaksanaan layanan bimbingan kelompok konselor yang telah bersertifikat pendidik memiliki nilai rata-rata $91,21 \%$ yang termasuk dalam kriteria sangat baik. Sedangkan konselor yang belum bersertifikat pendidik memperoleh nilai $66,81 \%$ yang termasuk dalam kriteria cukup baik. Hal ini dapat dilihat bahwa konselor yang telah bersertifikat pendidik lebih baik dari konselor yang belum bersertifikat pendidik dalam pelaksanaan layanan bimbingan kelompok. Pada pelaksanaan layanan konseling kelompok konselor yang telah bersertifikat pendidik memiliki nilai rata-rata $92,58 \%$ yang termasuk dalam kriteria sangat baik. Sedangkan konselor yang belum bersertifikat pendidik memperoleh nilai $65,76 \%$ yang termasuk dalam kriteria cukup baik. Hal ini dapat dilihat bahwa konselor yang telah bersertifikat pendidik lebih baik dari konselor yang belum bersertifikat pendidik dalam pelaksanaan layanan konseling kelompok.

Pada pelaksanaan layanan konsultasi konselor yang telah bersertifikat pendidik memiliki nilai rata-rata 91,67\% yang termasuk dalam kriteria sangat baik. Sedangkan konselor yang belum bersertifikat pendidik memperoleh nilai $67,16 \%$ yang termasuk dalam kriteria cukup baik. Hal ini dapat dilihat bahwa konselor yang telah bersertifikat pendidik lebih baik dari konselor yang belum bersertifikat pendidik dalam pelaksanaan layanan konsultasi. 
Pada pelaksanaan layanan mediasi pada konselor yang telah bersertifikat pendidik memiliki nilai rata-rata 91,67\% yang termasuk dalam kriteria sangat baik. Sedangkan konselor yang belum bersertifikat pendidik memperoleh nilai $67,69 \%$ yang termasuk dalam kriteria cukup baik. Hal ini dapat dilihat bahwa konselor yang telah bersertifikat pendidik lebih baik dari konselor yang belum bersertifikat pendidik dalam pelaksanaan layanan mediasi.

Berdasarkan dari hasil uji normalitas data (data tabulasi terlampir) didapatkan bahwa skor pada $P$-value $=0.200$ untuk Kolmogorov-Smirnov dan $P$ value $=0.334$ untuk konselor yang telah bersertifikat pendidik dan 0.134 untuk konselor yang belum bersertifikat pendidik pada uji normalitas Shapiro-Wilk. Kedua $P$-value lebih besar dari $\alpha=0,05$ sehingga data berasal dari populasi yang berdistribusi normal, jadi data konselor yang telah bersertifikat pendidik dan konselor yang belum bersertifikat pendidik berdistribusi normal. Hasil uji homogenitas pada kinerja konselor yang telah bersertifikat pendidik dan konselor yang belum bersertifikat pendidik adalah dapat dilihat dari nilai signifikansi 0,149 dan pada taraf signifikansi 0,05 atau 5\% makadiperoleh Fhitung>Ftabel maka artinya kinerja konselor yang telah bersertifikat pendidik dan konselor yang belum bersertifikat pendidik mempunyai varian yang sama atau homogenitas.

Berdasarkan dari hasil uji T-test data dari rata-rata skornya, terlihat bahwa kinerja konselor yang telah bersertifikat pendidik adalah 2.213 lebih tinggi dari pada rata-rata kinerja konselor yang belum bersertifikat pendidik yaitu 1.642. Kondisi ini menunjukkan bahwa kinerja konselor yang telah bersertifikat pendidik lebih tinggi dibandingkan dengan kinerja konselor yang belum bersertifikat pendidik.

Kinerja konselor merupakan hasil kerja konselor sebagai tenaga profesional yang memiliki keahlian dan pengalaman khusus dalam bidang bimbingan dan konseling, yang memiliki tugas dan tanggung jawab yaitu memberikan pelayanan kepada para peserta didik sesuai dengan kebutuhanya masing-masing, dalam kaitannya untuk membantu peserta didik mengembangkan dirinya secara optimal. Prayitno membaginya menjadi lima tahapan yaitu: (1) tahapan pertama: merencanakan program, (2) tahap kedua: melaksanakan 
program, (3) tahap ketiga: evaluasi pelaksanaan program, (4) tahap keempat: analisis hasil pelaksanaan program, (5) tahap kelima: tindak lanjut pelaksanaan program (Prayitno, 1997:129).

Sementara merujuk pada hasil penelitian Dwikurnaningsih (2011) menunjukkan tidak ada perbedaan yang signifikan antara kinerja Guru BK yang sudah bersertifikat pendidik dengan yang belum bersertifikat pendidik, dengan nilai $\mathrm{Z}=-, 221$ dan $\mathrm{P}$-value=0,825. Begitu pula hasil analisis pada variabel latar belakang pendidikan, menunjukkan bahwa tidak ada perbedaan kinerja Guru BK yang berlatar belakang pendidikan BK dengan yang berlatar belakang pendidikan non $\mathrm{BK}$ dengan nilai $\mathrm{Z}=-1,591$ dan $\mathrm{P}$-value=0,112. Sedangkan penelitian Sulasmono (2014) tentang kinerja mengajar guru adalah rata-rata kinerja mengajar guru-guru bersertifikasi pada kategori baik artinya tidak ada perbedaan yang signifikan. Hal ini dilihat dari observasi di lapangan bahwa kinerja guru sudah sesuai dengan perencanaan akan tetapi RPP yang digunakan masih berupa copy paste sedangkan dalam pembelajarannya sudah dilaksanakan dengan baik.

Jadi, dari pembahasan dan rujukan hasil penelitian sebelumnya dapat diketahui bahwa dalam penelitian ini terdapat perbedaan kinerja antara konselor yang bersertifikat pendidik dengan konselor yang belum bersertifikat pendidik dalam pelaksanaan layanan Bimbingan dan Konseling.

\section{SIMPULAN}

Berdasarkan hasil penelitian perbedaan kinerja konselor yang telah bersertifikat pendidik dan konselor yang belum bersertifikat pendidik dapat disimpulkan bahwa:

1. Kinerja konselor yang telah bersertifikat pendidik dalam pelaksanaan layanan orientasi, layanan informasi, layanan penempatan penyaluran, layanan penguasaan konten, layanan konseling perorangan, layanan bimbingan kelompok, layanan konseling kelompok, layanan konsultasi, dan layanan mediasi mendapat prosentase dengan kriteria sangat baik.

2. Kinerja konselor yang belum bersertifikat pendidik dalam pelaksanaan layanan orientasi, layanan informasi, layanan penempatan penyaluran, 
layanan penguasaan konten, layanan konseling perorangan, layanan bimbingan kelompok, layanan konseling kelompok, layanan konsultasi, dan layanan mediasi mendapat prosentase dengan kriteria cukup baik.

3. Terdapat perbedaan kinerja antara konselor bersertifikat pendidik dengan konselor yang belum bersertifikat pendidik. Konselor bersertifikat pendidik lebih baik kinerjanya dari konselor yang belum bersertifikat pendidik dalam pelaksanaan layanan $\mathrm{BK}$.

\section{DAFTAR PUSTAKA}

Asosiasi Bimbingan dan Konseling Indonesia. 2007. Penataan pendidikan Profesional Konselor dan Layanan Bimbingan dan Konseling dalam Jalur Pendidikan Formal (Naskah Akademik). Bandung : ABKIN.

Azwar, Saifudin. 2003. Metode Penelitian. Yogyakarta: Pustaka Pelajar.

Azwar, S. 2001. Reliabilitas dan Validitas. Yogyakarta : Pustaka Pelajar.

Dwikurnaningsih, Y. (2011). Perbedaan Kinerja Guru Bimbingan dan Konseling Berdasarkan Perolehan Sertifikat Pendidik dan Latar Belakang Pendidikan.

Prayitno. 1997. Pelayanan Bimbingan dan Konseling Sekolah Menengah Kejuruan. Padang: Penebar Aksara.

Sulasmono, B. S. (2014). Kinerja Mengajar Guru-Guru Bersertifikasi di Daerah Binaan 3 Kecamatan KrangganDoctoral dissertation, Magister Manajemen Pendidikan Program Pascasarjana FKIP-UKSW).

Undang-Undang Republik Indonesia Nomor 20 Tahun 2003. Sistem Pendidikan Nasional. 8 Juli 2003. Lembaran Negara Republik Indonesia Tahun 2003 No. 4301. Jakarta. 